University of Wollongong

Research Online

Faculty of Business - Papers (Archive)

Faculty of Business and Law

$1-1-2017$

The psychological contract of international volunteers: an exploratory study

Mary Barrett

University of Wollongong, mbarrett@uow.edu.au

Anne N. Cox

University of Wollongong, avo@uow.edu.au

Blake Woodward

University of Wollongong, baw90@uowmail.edu.au

Follow this and additional works at: https://ro.uow.edu.au/buspapers

Part of the Business Commons

Research Online is the open access institutional repository for the University of Wollongong. For further information contact the UOW Library: research-pubs@uow.edu.au 


\title{
The psychological contract of international volunteers: an exploratory study
}

\begin{abstract}
Purpose - The purpose of this paper is to investigate the psychological contracts (PCs) of international volunteers (IVs) in international aid and development organizations (IADS). Specifically, it explores four questions: how IVs form PCs; what the content of these PCs is; how IVs' PCs are maintained; and how they are fulfilled or breached.
\end{abstract}

Design/methodology/approach - The study used an inductive analysis of qualitative data: interviews with 27 IVs from a range of IADS.

Findings - The findings take the form of research propositions: RP1: IVs' PCs, like those of domestic volunteers, include relational, transactional and, especially, values-based elements, but the balance of these is influenced by their values-based PC; the self-directed way IVs join their organizations; and reliance on peers rather than the organization's management hierarchy. RP2: the PCs of IVs working for faith-based organizations have an additional element: spiritual support. RP3: the values-based PC means many transactional elements can be "adjusted away", making it difficult to breach these PCs. RP4: experienced volunteers have very minimal PCs, but are more likely than inexperienced volunteers to expect basic safety and adequately skilled colleagues.

Research limitations/implications - The authors suggest areas of new inquiry and specific ways each research proposition could be tested empirically.

Practical implications - To alleviate IVs' expatriation and repatriation adjustment problems, international aid organizations could facilitate the ways IVs already help each other. This would also help fulfill IVs' PCs.

Originality/value - IVs are a growing but underexplored group and aspects of their PCs may be unique.

\section{Disciplines}

Business

\section{Publication Details}

Barrett, M., Cox, A. \& Woodward, B. (2017). The psychological contract of international volunteers: an exploratory study. Journal of Global Mobility: The Home of Expatriate Management Research, 5 (2), 123-145. 


\title{
THE PSYCHOLOGICAL CONTRACT OF INTERNATIONAL VOLUNTEERS: AN EXPLORATORY STUDY
}

\begin{abstract}
Purpose This study investigates the psychological contracts of international volunteers (IVs) in international aid and development organizations. Specifically, it explores four questions: (1) how IVs form psychological contracts (PCs); (2) what the content of these PCs is, (3) how international volunteers' PCs are maintained, and (4) how they are fulfilled or breached.
\end{abstract}

Design/methodology/approach The study used an inductive analysis of qualitative data: interviews with 27 international volunteers from a range of international aid and development organizations.

Findings Findings take the form of research propositions:

RP1 IVs' PCs, like those of domestic volunteers, include relational, transactional and, especially, values-based elements, but the balance of these is influenced by their values-based PC; the selfdirected way IVs join their organizations; and reliance on peers rather than the organization's management hierarchy.

RP2 The PCs of IVs working for faith-based organizations have an additional element: spiritual support.

RP3 The values-based PC means many transactional elements can be 'adjusted away', making it difficult to breach these PCs.

RP4 Experienced volunteers have very minimal PCs, but are more likely than inexperienced volunteers to expect basic safety and adequately skilled colleagues.

Research implications We suggest areas of new inquiry and specific ways each research proposition could be tested empirically.

Practical implications To alleviate IVs' expatriation and repatriation adjustment problems, international aid organizations could facilitate the ways IVs already help each other. This would also help fulfill IVs' psychological contracts.

Originality International volunteers are a growing but under-explored group and aspects of their psychological contracts may be unique.

Key words: expatriation, faith-based organizations, international aid and development organizations, international volunteers, psychological contract, values-based contract, repatriation 


\section{INTRODUCTION}

The PC, defined as 'an individual's beliefs regarding the terms and conditions of a reciprocal exchange agreement between that focal person and another party' (Rousseau, 1989, p.123), has shown its value in explaining the attitudes and behaviors of employees (Zhao, Wayne, Glibkowski, and Bravo, 2007). The PC implies that an unwritten promise has been made and a consideration offered in exchange, binding the parties to reciprocal obligations. It is widely accepted that the PC exists within the minds of individuals and is therefore perceived differently by the parties to the employment relationship (see for example Shore and Tetrick, 1994; Lester et al., 2002). PCs have long been divided into two types: transactional contracts, entailing well defined, short-term, economic exchanges; and relational contracts that are embedded in webs of social concerns such as interpersonal relationships, reputation, and justice (Rousseau and McLean, 1993; Guzzo and Noonan, 1994).

Recently, the PC typological framework has been expanded to incorporate an 'ideology-infused' or values-based PC (Thompson and Bunderson, 2003), defined as 'credible commitments to pursue a valued cause or principle (not limited to self-interest) that are implicitly exchanged at the nexus of the individual-organization relationship' (p.574). Researchers such as Vantilborgh et al. (2012) argue that including the new dimension enables a more thorough understanding of the perceived mutual obligations between volunteers and not for profit (NFP) organizations. The concept of a values-based PC has underpinned recent studies of the PCs of volunteers, whose role involves helping others, freewill, and non-financial motivations.

This paper investigates an unexplored topic: the PCs of international volunteers (IVs) in international aid and development organization (IADs) ${ }^{1}$. Specifically, it explores four questions: (1) how IVs form PCs; (2) what the content of these PCs is, (3) how IVs' PCs are maintained, and (4) how these PCs are fulfilled or breached.

The topic is important for several reasons. First, expatriate volunteers are a large and growing segment of the global aid and development movement. The literature review shows that research on the PCs of both volunteers and expatriates has been growing for some time. However the PCs of international volunteers, who are both expatriates and volunteers, have not been explored.

Second, existing ideas about PCs are inadequate for understanding the PCs of this group. Clearly, there are similarities between expatriate employees and IVs and between domestic volunteers and

\footnotetext{
${ }^{1}$ International aid and development (IAD) is concerned with improving the living standards of poor people in poor countries. However there is no single agreed name for organizations delivering IAD (Fee, forthcoming).
} 
international volunteers. IVs face many challenges that parallel those of any expatriate assignment, including the need to cope with vast geographical, cultural and linguistic differences; diverse and dispersed stakeholder groups; and competing pressures to 'think global and act local' (Fee, 2017). These challenges are amplified by the urgent demands and people-centred objectives of much aid work (Quigley et al., 2015). Such challenges also characterize the work faced by domestic volunteers, such as dealing with the aftermath of natural disasters and working with homeless people. But there are also differences between these groups. Expatriate work involves living away from one's culture. The special nature of the volunteer-NFP relationship is likely to be reflected in the particular expectations that volunteers hold, the nature of the contract, and how violations are perceived and responded to (Farmer and Fedor, 1999). These contextual differences mean that understanding IVs' PCs requires treating the issue as unexplored territory. Much theory is context-dependent, and theories can be refined and improved through a more detailed understanding of their contextual limitations. Improving our understanding of the PCs of expatriate volunteers may therefore contribute more broadly to PC theory.

Third, improvements in theory can contribute to the improvement of management practices for populations of interest (here, IVs), leading to better engagement and retention. They may, via reversediffusion, lead to improvements to how people are managed in corporate, paid, non-expatriate settings.

The present study's methods were suited to an unexplored research problem. For example, rather than adopting existing instruments for measuring PCs and having IVs rate particular obligations, we held discussions with IVs about their motivations for volunteering, their degree of satisfaction with the experience and with the organization they worked for, and their intentions or otherwise about volunteering in future: all of which have been shown to be affected by fulfilment or breach of PC. We then analysed this data inductively to capture how IVs form their PCs, and what they perceive to be their obligations to, and entitlements from, their organizations. We also noted comments indicating perceived fulfilment or breach of PC. We then compared our findings to those concerning the PCs of other groups.

\section{Literature review}

\section{The formation of PCs}

Current research on PC formation in the for-profit (FP) sector focuses on pre-entry information collection (Purvis and Cropley, 2003; Rafaeli, 2006) and socialization (Thomas and Anderson, 1998; Tekleab, 2003). Pre-entry information about the employing organization, including employment advertisements which state the terms of employment influence newcomers' expectations (Rafaeli, 
2006; Tomprou and Nikolaou, 2011). Purvis and Cropley's (2003) study of PC formation between nannies and their employers shows that during interview and selection beliefs, expectations, obligations and promises are created. In the organizational socialization process, PCs are transformed: old PCs are adjusted and new PCs are formed, especially on the basis of information sourced from supervisors and peers (Tekleab, 2003). But how are PCs formed in the absence of a defined and formal interview, selection, and socialization processes, and when work is performed far away from the organization and supervisors?

Haslberger and Brewster (2009) argue that employees form PCs in the pre-employment stage, and that when employees are considering the offer of an international assignment - a significant career transition which heightens uncertainty - the PC is particularly salient. Employees' evaluations of the risks and benefits of the international assignment for their careers, and of their ability to adjust to the new environment and perform the task, are important in their decisions to accept or reject the assignment. Haslberger and Brewster (2009, p.382) speculate that an unusually high employee turnover rate upon return may be related to expatriates' perceptions that the PC has been breached. But IVs, by definition, go abroad not as organizational representatives but on their own initiative. In the absence of a paid employment relationship therefore, the risks and benefits expatriate volunteers assess in deciding whether to volunteer internationally will not match those of expatriate employees precisely.

Some studies have explored volunteers' PCs, studying the effects of individual characteristics such as functional motives and personality factors (Liao-Troth, 2005); the behavioral effects of breaches (e.g., Farmer and Fedor 1999; Kim et al., 2009), and the use of PCs to optimize contributions (e.g., Gaston and Alexander, 2001; Taylor et al., 2006). However the formation of volunteers' PCs remains unexplored. Haski-Leventhal and Bargal (2008), in a study of Israeli volunteers working for at-risk youth, explored the effects of pre-entry activities and socialization: their Volunteering Stages and Transitions Model (VSTM) indicates five phases in volunteers' socialization: nominee, newcomer, emotional involvement, established volunteering, and retiring.

Volunteers' socialization, as indicated in the above study, appears to involve deep changes and shifts in their activities, perceptions, attitudes, emotions, and relationships with others. Other players, such as peers, clients and representatives of the organization appear to be important. The VSTM has influenced much subsequent research into volunteering, but may not explain IVs' socialization or PCs adequately. While factors such as forming emotional involvement may well be common to these processes, the last four stages are heavily influenced by the selection process, training activities, and other aspects of volunteer induction which can resemble the corporate environment in their rigor and 
formality. But if these features of organizational entry are absent (as we will show they frequently are for IVs), how are PCs formed?

Our first research question is therefore:

RQ1: How are the PCs of IVs formed?

\section{The content of the psychological contract}

PC content refers to the items that the employee and the organization believe they owe one another (Rousseau, 1995; Conway and Briner, 2005). Following Rousseau's (2005) conceptualization of the PC as an individual phenomenon, contemporary research into PC content focuses on employees' expectations. If these are explicit and limited to meeting the terms of the employment contract (Guzzo and Noonan, 1994), they determine a largely transactional contract; if they go beyond the employment contract and also delineate the employee's social relations and non-work life, they affect the relational contract.

Recently, the motivation of expatriate aid and development workers has attracted much empirical research. IVs' goals in joining IADs appear complex and varied. Oberholster et al.'s (2013) study of expatriate motivation in religious and humanitarian NFP organizations found eight latent motivational factors: career development, economic factors, international experience, escapism, altruism, outsider support, family life, and location. Of those factors, the strongest was altruism. Farmer and Fedor (1999) note that while there are similarities in the PCs developed by volunteers and paid workers, 'because volunteers' reasons for affiliation with the voluntary organization are primarily symbolic, not material, the 'coin' in which they see themselves 'paid' is also symbolic' (Farmer and Fedor, 1999, p.362). Fee (2017) argues that increasingly IAD expatriates are motivated by more pragmatic and self-directed outcomes, such as adventure and excitement, or professional and personal development.

As volunteers do not expect to be paid, their PCs are more likely to be relational than transactional, with volunteers seeking explicit feedback on the value that they contribute to the organization's goals, and feeling that the organization cares about their well-being. The level of support the volunteer believes he or she is receiving from the organization can increase involvement and reduce withdrawal or turnover intentions (Farmer and Fedor, 1999). Transactional PCs are not necessarily overtly relevant to volunteers, and it is PC breaches of relational contract obligations that may negatively affect performance (Taylor et al., 2006). 
The new 'ideology-infused' or 'values-based' PC (Thompson and Bunderson, 2003) is often invoked in studies of volunteers. The values-based aspect reflects their concerns for the community, service to humanity, connectedness to the environment, compassion and care, and voluntary selfless work (Burr and Thomson, 2002). Workers' focus shifts beyond themselves and the organization to a third party beneficiary: society (or some segment thereof), or to an intangible principle (Thompson and Bunderson, 2003).

Volunteers typically expect NFP organizations to demonstrate a credible commitment to an espoused cause, and it is fulfilment of this value-based obligation that determines their perception of PC fulfilment or breach (Vantilborgh et al., 2012). Considering occupational ideologies, O'Donohue, Donohue and Grimmer (2007) and O'Donohue and Nelson (2009), examined the importance of ideological values and beliefs about work to the PCs of employed medical and scientific professionals. According to O'Donohue, Donohue and Grimmer (2007), the failure of the organization to deliver on such perceived obligations and to support for the values of the scientific community significantly affects these employees' perceptions of their PCs. Ralston, Downward, and Lumsdon (2004) found that volunteers expected to receive adequate management, clear and correct communication, appreciation, and practical support. O'Donohue and Nelson's (2009) research on volunteers in Australian hospitals found that their PCs typically included economic, socio-emotional and ideology-related elements.

Vantilborgh et al. (2012) studied 25 volunteers from two similar Belgian NGOs, and found that they perceived 12 distinct organizational obligations, which are summarized in Table 1:

\section{Place Table 1 about here.}

So far, however, the content of IVs' PCs, especially in IAD organizations, remains unexplored. This prompts our second research question:

RQ2: What is the content of IVs' PCs?

\section{Maintenance of the PC}

PCs are dynamic, ongoing and evolving (Rousseau, 1995; Herriot and Pemberton, 1997). New items are added over time and that expectations are adjusted as perceptions about the employer's commitment evolve. In the FP sector, the emphasis in PC maintenance is placed on the company's role. In particular, HR policies and practices are considered influential. The context helps to shape not only the content of the exchange that forms the PC but also responses to it (Guest, 2004). Tsui et al. (1997) point out that when there is an over-investment by the employer in the employer-employee 
relationship, employees perform better, demonstrate more citizenship, and express more affective commitment to their employer. Guest and Conway's (2002) study of 1,306 senior HR managers points to the need, in maintaining employees' PCs, to consider human resource practices, such as training and development, recognition for innovation, feedback on performance, interesting work, fair pay, attractive benefits, job security, safety, and open two-way communication. Their study confirms an association between high-commitment human resource practices and positive employee attitudes and behavior.

NFP organizations seeking to maintain their volunteers' PCs may face even greater challenges than their FP counterparts. O'Sullivan (2010) demonstrated that strategic IHRM practices pose a significant challenge for development INGOs, a challenge complicated by the limited financial resources that prevent them from paying for the IHRM expertise that might enable them to move beyond immediate operational issues. This contrasts with multinational corporations that can spend up to $\$ 2$ million per expatriate on salary and expenses during a four-year assignment (Jassawalla, Asgary and Sashittal, 2006). Yet paid employees and volunteers seeking to maintain their PC may be similar in their need for adequate HR policies and practices.

The values-based dimension of the PC in volunteer and other contexts also presents new potential for breaches. Cunningham (2010, p.699) finds 'clear limits' to how far the value-based aspects of the PC will compensate for unfulfilled obligations on the economic and social-emotional dimensions. While the participants in Cunningham's study were employees, Fee (2017) has also pointed out the adverse effects on the commitment of IAD volunteers when organizations over-emphasize 'administration' at the expense of the organization's mission. Another adverse effect, termed 'value interpenetration', arises from mission drift, including instances of the organization pursuing funding from agencies insufficiently committed to its particular cause.

We can ask therefore, in the light of the informality of IHRM practices and the scarcity of resources in many IADs, how the PCs of IVs are maintained. Accordingly, our third research question is:

RQ3: How is the PC of IVs maintained?

\section{Breach/fulfilment of PC}

A breach of PC occurs 'when one party in a relationship perceives another to have failed to fulfil promised obligation(s)' (Robinson and Rousseau, 1994, p.247). As this definition implies, the opposite of breach is fulfilment, thus establishing a breach-fulfilment continuum (Conway, Guest and Trenberth, 2011). In FP organizations, conflicts of interests arise when there is a disparity between the expectations of expatriates and those of their employers (Rousseau, 1995). In particular, as Paik, 
Segaud and Malinowski $(2002$, p.646) point out, ' $[\ldots]$ the expatriate accepts the assignment for career advancement, compensation and adventure as opposed to the company who sends an expatriate for the purpose of transferring the home corporate culture and meeting project objectives'. This mismatch of perceived obligations can lead to the breakdown of the PC, with effects that are severe, long-lasting and difficult to repair (Rousseau, 1989). Studies have found breach to be associated with anxiety, depression and hurt (Conway and Briner, 2002); job dissatisfaction (Tekleab and Taylor, 2003); decreased trust and commitment (Lester et al., 2002); cynical attitudes towards the organization (Johnson and O'Leary-Kelly, 2003); decreased performance (Lester et al., 2002); employee retaliation through sabotage, theft or aggression (Morrison and Robinson, 1997); turnover intention (De Hauw and De Vos, 2010); and employee departure (Thompson and Bunderson, 2003). How IVs react to breaches of their PC is, however, unknown.

Expatriates' turnover intentions due to breaches of PC can however be remedied using HRM practices. For example, Cesário, Chambel and Guillén (2014) considered a sample of 100 expatriates from a Portuguese company, and investigated the relationships between perceived HRM practices and their PC fulfilment and turnover intention. The fulfilment of their expectations regarding the international assignment and their professional reintegration upon repatriation enhanced their PCs and made them less liable to leave the organization.

There are two main causes of PC breach in the NFP sector. Firstly, volunteer organizations often lack a clear understanding of volunteers' needs and expectations and have limited HR solutions to conflicts. Anderson's (2001) research found that mission organizations were typically unaware of the need to manage or actively support missionaries and that few mission boards had systematic, ongoing counselling programs for new missionaries. In the international sphere, there are considerable IHRM challenges that NGOs face that can readily lead to PC breaches, (O'Sullivan, 2010). As noted earlier, many IADs face challenges as great as their FP counterparts, and often deal with more stressful human-centred issues.

This review shows that what constitutes a breach of IVs' PCs have not been explored. This prompts our fourth research question:

\section{RQ4: What constitutes breach or fulfilment of IVs' PCs?}

\section{METHODOLOGY}

As qualitative methods are particularly suited to examining under-explored environments, we used a qualitative research approach. Scholars of the PC have argued for more qualitative research. Early writers on the PC such as Argyris, Levinson and Schein used a qualitative perspective (Rousseau, 
2000). Because the PC is perception-based (Guest et al., 1996), idiosyncratic (Rousseau, 1989), context-dependent (Conway and Briner, 2002), and a social construction of reality (Rousseau, 1995), a qualitative method which generates data providing well-grounded, rich descriptions and explanations in identifiable local contexts (Miles and Huberman, 1994) is needed to effectively explore its constructs. According to Conway and Briner (2005, p.109), 'the near exclusive use of the survey method has no doubt hampered conceptual, theoretical, and empirical advance in this area'. By contrast, qualitative research 'produces data of idiosyncratic experiences and interpretations of the psychological contract, grounded in the language of employees and organizational context.'

\section{Research techniques}

The study was underpinned by an inductive analysis, which allows theory (e.g. concepts, ideas, themes) to emerge from qualitative data. This inductive approach influenced our sampling method, data generation, and analysis.

\section{Sampling}

In order to include different types of IAD organizations and also IVs who varied in gender, age, number and duration of volunteer assignments, and total length of time as a volunteer, we used theoretical (or purposive) sampling.

Initially, we invited $10 \mathrm{IVs}$ in IAD organizations whom we knew to participate in the research. (None of the researchers worked or had worked in the same organization as these IVs.) Then, through a snowball technique whereby these IVs advised others, a sample of 27 volunteers was compiled, including 11 long-term and 16 short-term volunteers. The snowball technique enables researchers to access difficult-to-reach or hidden populations (Atkinson and Flint, 2001), an important consideration in this study. The countries in which participants undertook their assignments all presented a substantial cultural contrast with the participants' home country, Australia. The type of work performed by volunteers varied. Table 2 summarizes demographic information about the volunteers and their assignments.

\section{Insert Table 2 here}

\section{Data generation}

Data was generated via semi-structured interviews using both closed and open-ended questions. The term 'data generation' rather than 'data gathering' emphasizes that data is generated from the interaction of the researchers and interviewees. Using open-ended questions that allow interviewees to project their views and researchers to probe these, is consistent with an inductive approach. The 
questions were covered in a flexible manner but allowed us to explore our research questions concerning PC formation, content, maintenance and fulfilment/breach, and also covered personal details and the nature of the volunteer's association with the IAD; their motivation to volunteer; how they joined the IAD; their expectations of the organization during expatriation and repatriation and the extent to which these had been met; their perceptions of their experiences during and after the overseas assignment; and their satisfaction with the experience.

Thirty-two interviews were conducted; participants were interviewed at different stages of their assignment. Most interviews were conducted face-to-face, but a few were conducted by phone or via email because of geographical constraints. Emails were also sent to seek clarification when needed.

\section{Data analysis procedures}

An inductive research strategy typically entails beginning the analysis as soon as the researcher has a reasonable body of data. As ideas, concepts, and themes emerge from the data, the researcher can refine the questions and also search out additional participants to probe tentative findings further. Accordingly, the analysis began after three interviews had been recorded. We noted recurring themes, areas of similarity and contrast among them, and new issues, leading us to create additional questions that were used in later interviews, and to add new participants to allow the new issues to be explored. The emergent themes were also compared with the literature. Consistent with the objectives of much qualitative research, our aim was not to generalize, but rather to produce research propositions which could be tested in subsequent studies.

\section{FINDINGS}

The study's findings are organized according to our research questions.

\section{The formation of IVs' PCs}

The formation of IVs' PCs reflects the informality of the processes by which many INGOs admit volunteers, and the volunteers' self-directed approach to organizational entry. When IVs chose an IAD, got information about it, judged their 'fit', learned about, embarked on and actually performed the volunteer task, and returned home afterwards, they had remarkably little formal contact with, or advice from, their IADs' 'management'. For their part, IADs paid little attention to formal selection processes, and there was evidence that volunteers had already decided that they and the organization would be a good match before they offered to volunteer:

Jeff: Volunteers are mature people... [IAD] leaves it to you to make the sensible decision. 
Volunteers were left to seek organization information, and choose an IAD and a mission they felt suited them.

Michael: [Name of specific club] has a history of doing overseas work, particularly in Papua New Guinea.... One of the reasons why I joined this club was because, at the personal level, most of my career has been overseas. My background is international business development. I've worked in twenty different countries around the world.....

The socialization process described by Haski-Leventhal and Bargal (2010) assumes volunteers join pre-existing teams without knowing members in advance. In contrast, our volunteers paid attention to who might be their team members. This could change a decision to volunteer:

Jude: If somebody in the club is going that you might not get on with, you would make a conscious decision not to go this time as you don't want to spend two weeks in the bush with that guy.

This self-directed approach extended to other pre-assignment activities. Volunteers tended to rely on honest communication with past volunteers or more experienced peers:

Michael: There is a legacy coming through by word of mouth. I don't think there is any formal training. I think we have peer knowledge.

Joyce: One of the things that we do before we go, probably for three months...Every two to three weeks we get together as a group with the people that are going. We talk about the event, we talk about what we are about to do, the processes, what type of things that we need to take with us, all these types of things. .... There is no formal preparation.

Commitment to the IAD was strengthened by the considerable prior financial commitment volunteers often had to make:

Jeff: People have to pay for the privilege.... If people can't afford it, they've got two options: they either go out and raise some money for themselves, friends, family members, whatever, or they don't go....

At later stages, some IVs also experienced deep shifts in their emotional reactions, which they managed by relying on peers, who came to resemble a family: 
Renee: You might have problems coping, you will feel homesick, but counselling services were unavailable.... Financial resources were limited but you can always cry on your friend's shoulder.

Jeff: When you go over there you are like-minded people with a humanitarian interest so you do become a family. And the people we work with all become very close so that is your support mechanism. A lot of us have seen awful things [people who are dying, decomposing corpses in natural disasters], but I think it's that group bonding, and that family situation that [means] you just move on.

IVs from faith-based organizations frequently mentioned God as an alternative source of assistance, who sometimes even obviated the need for knowledge:

Karen: I didn't know what to expect - I didn't know if I would be living in a tin shack, or what! But God really looked after me! He nurtured me at every step. I was worried that I'd be lonely, being so far from my friends and family and everything familiar to me, but God gave me some wonderful, supportive friends, who were focused on God.

IVs, like other workers, form their expectations by seeking and getting information, and forming and adjusting expectations. They are self-directed in selecting their organizations. They extend the 'paid/unpaid' distinction by 'buying' the 'privilege' of volunteering. Having a previous values-match with the organization, e.g. through being a non-volunteering club member, makes IVs much less reliant on formal management to understand the organization's ethos, and the mutual obligations. Peers, rather than 'the hierarchy', are not merely important in providing for volunteers' socialization, they dominate the process. Peers become 'family' sources of information and support: and for some IVs, God is the ultimate family member.

\section{The content of IVs' PCs}

Our IVs' PCs had seven expectations: communication with the IAD and with family, emotional/psychological assistance, to contribute to the organization's mission, input into management and governance, and recognition. Support and training were expected by some but not all IVs. IVs in faith-based organizations expected spiritual support in addition to these seven. All the interviewees expected basic practical help, often simple logistics, advice on vaccination requirements and bank accounts, and so on. But many emphasized that their expectations of practical help were minimal: 
Wesley: As I did this trip four times and was very familiar with the organization and its local staff, my expectations around the assistance they would provide were primarily operational. I expected them to make decisions that would keep the group safe, but never expected them to provide further personal assistance when I could arrange this myself.

Wesley was typical of the older, experienced volunteers who expected that the IAD would ensure their safety, including emergency exits from disaster zones, and assist with communication in remote locations.

\section{Communication}

Regular communication from the IAD and help from the IAD to keep IVs in contact with their families was mentioned as an expectation by five volunteers, one of whom said that the assistance was offered but limited. Andrew mentioned face-to-face visits from IAD members:

Andrew: The [IAD mission's wing] member would visit once a month for each of the three months. [We] caught up for coffee, chatted.

Other volunteers kept in touch with their families and IAD head office using their own means. When the organizations failed to provide even basic assistance or when IVs were confronted by distressing circumstances, some IVs from faith-based IADs confidently expected that God would meet their needs:

Wesley: Our expectation was often more that God would look after us and provide for our needs, rather than placing that expectation on our organization. The main expectation of assistance we had of the organization was to arrange the booking and logistics ..... But even if those failed we strongly believed that God would still provide us with opportunities to serve and fulfil our reason for being there.

Kara: Some [patients] you can save, some you can't. .... in Vietnam, the patients have to suffer for years in isolation and have no hope because they are just so poor .... Praying within our group gives me inner strength, reinforces my belief in what I am doing, and keeps me going.

\section{Emotional/psychological assistance}

IVs often expressed a need for emotional and psychological support, sometimes when they witnessed distressing events during the assignment, but particularly when they returned home. The following 
quotes are typical of many IVs' sense of displacement and the distress they felt when comparing the luxurious circumstances of home with the circumstances they had left.

Karen: Reverse culture shock hit me hard. After a full year in an extremely conservative culture (don't speak to men and don't look them in the eye, dressing conservatively, no PDA, not using 'sex to sell', no kissing on TV, etc), coming back to Australia was such a shock. I found it hard to accept what a godless, debauched and materialistic culture we live in. My community was not as close or supportive as it had been in Cairo. People placed too much importance on 'first world problems'.

Renee: A month or two after I arrived back, I went into a supermarket to buy some groceries where I faced this refrigerator filled with a wide variety of milk... whole milk, low-fat milk, fatfree milk, rice milk, almond milk.... All of a sudden, I felt sad and angry. I had just come back from a land where food is scarce and milk is a luxury. A lot of babies there do not have enough milk because their mothers do not have enough food to eat. And here in front of me, packed in a refrigerator, there are choices! I could not cope with it....

These emotional reactions contrast with the confidence on-site that peers or God would provide emotional support or prayer. Very rarely was the IAD expected to do so. Andrew described the debriefing process, critically, as 'somewhat task-oriented', and explained that the IAD 'examined every aspect of the job' asking him 'what [he] felt about it [the assignment]' and the 'strengths and weaknesses of the leaders of the trip': he appeared to have expected the organization to be more interested in his emotional reactions to his experiences.

Most debriefings were simple and informal, and were done by or with other volunteers. For Stacey, the debriefing session involved a 'sit-down-and-reflect session' with other volunteers from the IAD who had travelled at the same time. Three short-term volunteers said they initiated a presentation so as to share their experience with other club members.

Michael: We reported back to the club. We put a presentation together about what we did, what we achieved... Compulsory probably is too strong a word. It is expected but in [name of the IAD] there is no 'must' but people in fact do it.

This debriefing was counted as an IV obligation rather an organizational obligation.

Friendship 
As noted earlier, IVs often remarked on the close, family-like friendships they made, often as a result of bonding through shared, sometimes traumatic experiences. After they returned home they often missed these friendships:

Karen: I missed all that I'd had in Cairo so much and had no one to share that understanding with. I was conscious of always saying, "In Cairo...."

\section{To be helped to keep contributing}

Michael's presentation to the home base of the IAD (see above) was typical of the ways IVs wanted to be helped to keep contributing. Ongoing contact from the IAD via newsletters and/or get-togethers after they returned home was mentioned by 21 IVs who clearly saw these as forms of support. They also mentioned wanting to continue their own communication with their IADs, not as volunteers but as regular club or church members. Several commented that their IADs could have done more to encourage and facilitate IVs' further contributions. The following comments were typical:

Graham: They (IADs) need to continue their excellent relationships that they have with their workers.

Sarah: They could certainly use the skills of volunteers much more after we come back. [...]

They are not well set up to deal with the training and experience that we have and I think that is a loss for them.

\section{Input into management and governance}

Sarah received an invitation in the mail to vote for her IAD's executive committee at the next annual general meeting. However she felt she did not know the candidates well enough to make an informed vote, something she saw as a failure on the IAD's part.

Sarah: If they [IAD] had given me an opportunity to meet them [the candidates] I would taken it. Then I would have been much more likely to actually vote.

\section{Recognition}

Volunteers welcomed recognition or appreciation from their IAD:

Joyce: We are very proud; they [IAD] gave everyone a certificate in a ceremony... It really brings a tear to your eyes and it makes you feel, 'Geez, they really appreciate what we have done'. 
For many, however, the opportunity just to do the work was its own reward:

Wesley: You know that you will be placed in situations way outside of your comfort zone and in situations that you can't control. You know that there is only so much that the organization and the people around you will be able to do to help support you and at times that won't be enough. But you don't hold that against them. You actually feel grateful to the organization for enabling you to gain these incredible life experiences.

\section{Training}

Despite the fact that many volunteers obtained their training from their peers rather than the IAD, others expressed an expectation of being trained. Andrew was undertaking a long-term assignment. He could not easily choose who to volunteer with, and so felt the organization should ensure that those selected were good team-workers.

Andrew: Some personality types need extra care when they are assigned to a team: both for their sake and for the sake of the team.

Tina, 56, another older volunteer on a long-term assignment, also said that volunteers should have 'good Bible and cross-cultural training', which, she pointed out, her IAD did not provide.

Table 3 compares IVs' expectations of their organizations with their equivalents in Vantilborgh et al. (2012).

\section{Place Table 3 about here.}

The two lists have many items in common, but also reveal contrasts. The absence of autonomy from IVs' PC seems surprising given their self-directedness in all phases of organizational entry. But selfdirectedness is not the same as autonomy: IVs did not seek to do their volunteer tasks their own way, but relied on previous practice. Not expecting benefits (tangible inducements) is unsurprising since they worked in IADs. IVs valued communication with the IAD and family and their home organizations, but not communication with their organizations about basic tasks. They perhaps expected their IADs to demonstrate a credible commitment to their missions, but they were already confident about this because of their previous association with the organizations. Moreover, the fact that they did not mention failure of credible commitment may have meant that no breaches had occurred; this may also explain the absence of 'fairness' from IVs' PCs. More experienced IVs seemed more likely than the less experienced to expect practical support, especially basic safety. Expectations about training, a staple of PCs in FP and NFP environments, presented a similar split in the sample. IVs relied for training and advice on their peers - or in some cases on God - virtually to 
the exclusion of their organizations. Others with more experience believed that their organizations should provide training.

\section{How IVs PCs were maintained}

IVs maintained their PCs by reducing their perceptions of organizational obligations on-site or after the first volunteering trip. IVs' awareness of IADs' limited resources, the reality of the local conditions, and the realization that 'you are on your own' all reduced volunteers' expectations.

Renee: I realized that I had been somewhat naïve in my expectations. Our teaching program mission was to provide educational support for disadvantaged communities, some of which were in remote locations. You might have problems coping, you will feel homesick, but counselling services were unavailable. [IAD]'s financial resources were limited.... but you can always cry on your friend's shoulder.

\section{Fulfilment/breach of IVs' PCs}

Table 3 indicates that IVs' PCs, like those of domestic volunteers, contain transactional, relational and values-based items. However IVs' PCs were more difficult to breach and easier to fulfil than those of domestic volunteers. Table 3 suggests some explanations for this. First, IVs had fewer expectations of their organizations than regular volunteers, so there were fewer opportunities for breach. Second, PC items tended to be 'adjusted away'. Third, some breaches, such as failure to encourage IVs to keep contributing to the organization's mission after they came home, were seen as losses for the organization, rather than the volunteer. Finally, obligations such as communicating about the overseas assignment became obligations of the volunteer rather than the organization.

\section{CONTRIBUTIONS TO THEORY AND SUGGESTIONS FOR FURTHER RESEARCH}

In this paper we considered the PC in a novel context: volunteers in IADs. Our results suggest that IVs, like regular volunteers, have transactional, relational and, especially, values-based expectations. This strengthens previous research concerning the composition of the PC. The contrasts we found between volunteers and IVs also refine PC theory. First, the IVs' informal, self-directed organizational entry differed from the VTSM (Haski-Leventhal and Bargal, 2008): peers rather than IAD management influenced IVs' PC formation. The content of IVs' PC was also different, with fewer items, many of which could be 'adjusted away' during the process of PC maintenance. IVs 
subtracted rather than added items to their PC, making it difficult to breach. Finally, the PC of IVs seemed very easy to fulfil largely because IVs fulfilled their PC themselves, sometimes with help from God.

These propositions both extend PC theory and can be readily tested. The transactional, relational and values-based categories of IVs' PC could be tested using the critical incident approach that Vantilborgh et al. (2012) used to categorize domestic volunteers' PCs. They also tested which type of PC, transactional, relational, or values-based, was more likely to be breached or fulfilled, and the same could be done for IVs' PCs.

The influence of IV experience and faith commitment on the strength of each PC contract item (transactional, relational and values-based) could also be tested using structural equation modelling techniques.

The apparent high resilience of IVs' PC could be tested using 'threshold' models of the PC (Rigotti, 2009). 'Thresholds' are changes of attitude that follow breach perceptions, and they have been used in other work contexts to predict consequences of breach such as leaving the organization. A similar approach could be used to predict when even virtually 'breach-proof' IVs would stop volunteering, reduce their effort, and so on, and which dimensions of the PC contract (transactional, relational or values-based) are more likely to provoke these reactions.

\section{IMPLICATIONS FOR PRACTICE}

\section{Formation of IVs' PC}

Researchers have characterized PC formation in the FP sector as a process of information-seeking (e.g., Rousseau, 1995) where both organizational and individual factors exert influence. Individuals determine how information is interpreted and what they are seeking from the employer. Our IV volunteers also actively sought organizational information and volunteering opportunities. However their information about what the assignment would entail came mainly from chats, presentations and 'debriefings' with their peers - current or previous volunteers who had done similar assignments rather than members of the IAD 'hierarchy'. Volunteers helped each other through their opinions, assurances, and interpretations - 'pertinent information without distortion' - such that those who found the 'realistic preview' unacceptable would self-select out of the assignment. This process helped applicants to 'feel greater commitment to the decision to accept the job which leads to more positive attitudes and lower probability of turnover' (Reilly at al., 1981, p.828). Further, IVs engaged in a self-selection process, and tended to assume in advance that they would have a long-term 
relationship with the IAD. Self-selection facilitated good matches between applicants' characteristics and assignments.

Many volunteers financed their own trips, which ensured high personal commitment to the assignment. The overall effect on the formation of their PCs was, paradoxically, both a stronger PC volunteers were strongly committed to the goals of the IAD from the outset - and one which was idiosyncratic and flexible. When they encountered situations which did not correspond to their expectations, rather than perceiving their PC as having been breached they criticized their own preconceptions as naïve. The almost complete absence of pre-departure training tended to reinforce the self-directed nature of their PCs. In the light of this, IADs should help previous volunteers to advise prospective volunteers. This would help the prospective volunteers to make informed decisions and simultaneously fulfil the PC of previous volunteers.

\section{Content of IVs PC}

Our results show that the content of IVs' PCs before and during the assignment consisted of fewer expectations than volunteers' PCs. Indeed, what was not part of IVs' PCs was as noteworthy as what they contained. During the assignment practical support was occasionally seen as inadequate for the situations IVs faced, but rather than perceiving a breach they adjusted their PCs. What was overwhelmingly important was emotional assistance, including (for IVs in faith-based organizations) spiritual support. Overall, therefore, IVs' PCs included relational, transactional, and values-based expectations. However the transactional elements appeared much less important than relational and values-based items. And unlike employees in the FP sector and expatriates in IADs whom Fee (2017) found to be motivated by adventure and excitement, or professional and personal development, our IVs' expectations were focused very much on the IAD's goals, which they had previously determined to be congruent with their own values. IADs should ensure that IVs are able to access emotional and spiritual support - not from the organization, but from groups important to the IV, such as their peers, families, and support communities at home.

\section{Maintenance of IVs' PC}

In terms of maintenance of the PC in the FP sector, social exchange theories have informed the relational/transactional division in PC research (e.g., Shore et al., 2006). This study suggests that in the IV expatriation and repatriation context, the transactional side of the PC is largely absent and that volunteers are engaged and connected to their IADs by relational and values-based PCs. The minimal assistance provided by IADs, particularly for short-term volunteers, the volunteers' low expectations of assistance, and their propensity to assist themselves is consistent with Haines, Saba and Choquette's (2008, p.445) finding that individuals driven by intrinsic motivations typically express 
greater willingness to accept international assignments, and in more country destinations, than those driven by extrinsic needs. These individuals typically possess 'high levels of interest, excitement, and confidence' and 'attribute their participation more to the enjoyment or satisfaction inherent in the activity than to any extrinsic incentive'.

With little support from IADs, the IVs in this study developed their own family-like support networks of other volunteers, which also reinforced the relationships that they had with each other and with their IADs. In addition, when volunteers chose an organization to volunteer with, they tended to align personal and spiritual motives with the values and spiritual affiliation of the organization. An expectation of spiritual support may be unique to the volunteers in faith-based IADs. All this highlights the vital importance of relational and values-based PCs for volunteers and for IADs.

\section{Fulfilment/breach of IVs' PC}

In the FP sector, the organization is the chief source of PC fulfilment and HR policies strongly influence PCs. Guest and Conway (2002) found that explicit communication of promises and commitments during recruitment created clear PCs. Sims (1994) argues that a primary goal of training departments should be to help employees understand what they can expect to give and receive from the organization, thereby helping to create an agreed PC. In contrast, we argue that in IADs and the NFP sector, the volunteers are themselves the main driving force of PC development and fulfilment. Some volunteers, during their initial experiences, even decrease their initial expectations of their IADs' assistance through direct exposure to reality in the host country, and social interactions with other volunteers. This study thus highlights the effects, on IVs' PCs, of their self-directed behavior and reliance on their peers.

This study also points out the importance of repatriation assistance in IADs, with interviewed IVs expressing strong discomfort with aspects of re-entry. In the repatriation phase, their IADs offered few conventional forms of assistance, especially in the repatriation process. Yet the IVs did not attribute responsibility to the IADs for solving this classic problem. This can be explained by IVs' altruistic and/or spiritual motivation for taking on the assignment. For many, unexpected hardships were evidence that God was enabling them to serve others. In terms of a breach with the IAD, the post-assignment reflections of a few IVs suggested that they regretted only that the IAD did not make more use of their experience to guide future volunteers. IVs' perceived fulfilment of their own PCs and their organizational commitment were not disturbed. Despite the frequently arduous nature of their work and the comparative lack of IAD support our volunteers were highly satisfied with the assistance they received and their experience overseas, particularly their contributions to society, enshrined in their values-based PCs (Thompson and Bunderson, 2003; O'Donohue and Nelson, 2009). 
We note that the IADs overlooked specific strategies to ease expatriation and repatriation processes, probably due to lack of resources and expertise, lack of awareness of the difficulties facing volunteers, the assumption that volunteers did not experience re-entry difficulties because they were not away from home for long, and loss of contact with returnees. Our study suggests that relationships between volunteers and IADs are often long-term and, for the benefit of the IADs, need to be managed and maintained.

We would not suggest, however, that IADs should ape the FP sector in the type of support they offer. Rather the IADs' HR departments offer information about assignments in a formal, standardized manner, they might instead facilitate volunteers' existing forms of mutual assistance. In particular it would add to the fulfilment of many IVs' PCs if they were invited to share their experiences with the next groups of volunteers. Moreover, it is known from previous research that prospective employees trust the information they receive from current employees more than that from the HR department, and that new hires made as a result of the recommendations of current employees are typically a good fit with the organization (Ryan and Delany, 2010). This strongly suggests that the way international volunteers form their PCs is effective both for themselves and for their IAD.

\section{CONCLUDING THOUGHTS}

Our study focuses an important but under-researched topic: the PC of volunteers in IADs. These organizations appear to have largely unique working environments where intrinsic motivation and organizational commitment are very high and demand for financial rewards and assistance very low (Becchetti, Castriota and Depedri, 2013). Volunteers are self-directed, yet their goals remain highly congruent with those of the organization. These conditions would likely be regarded by the FP sector as highly desirable. Further research could investigate how the mechanisms that IADs use - such as 'family support' structures - might be adopted by corporate organizations in the expatriation and repatriation processes.

When forming their PCs, IVs rely mainly on information they seek out themselves and obtain from co-volunteers. Once in the field, they adjust their expectations in the light of their own and their covolunteers' experiences. Accordingly, international volunteers' PCs appear to be more self-and-peerdirected than the PCs of employees and domestic volunteers. The assumption in PC theory that psychological contracts are always formed between individuals and formal institutions or representatives of the organization they work for may be too limiting. Volunteers stressed that they relied on 'open, honest communication' which effectively constituted a 'realistic job preview', but this communication was typically with informal friends rather than formal spokespersons. The real 'otherness' of the 'other party' to the psychological contract referred to in Rousseau's (1989) definition needs to be taken seriously. 
In the present study IADs seldom breached the modest PC expectations of their volunteers: even when the IADs' practical assistance did not meet expectations, volunteers revised their expectations downwards. However the same might not be true if a volunteer perceived that a co-volunteer had not given accurate information: future researchers might examine what happens in such cases. Depending on the reason the (new) volunteer perceived for the inaccuracy, he or she might well perceive a PC breach. Even then, the fact that volunteers choose the organization they volunteer with may lead them to put the error down to their own poor judgement, naivety or lack of experience. In all, the behaviors and thinking of volunteers in IADs have much to offer to PC theory and management practice, as well as the communities they serve.

\section{ACKNOWLEDGEMENTS}

We are indebted to the anonymous referees of this journal and the editor of this special issue, $\mathrm{Dr}$ Yvonne McNulty, who all made several suggestions adopted in this article.

\section{REFERENCES}

Anderson, B.A. (2001), Expatriate Management: An Australian Tri-Sector Comparative Study. Thunderbird International Business Review, 43(7), 33-51.

Atkinson, R. and Flint, J. (2001), Accessing Hidden and Hard-to-Reach Populations: Snowball Research Strategies. Social Research Update, 33(1), 1-4.

Becchetti, L., Castriota, S. and Depedri, S. (2013), Working in the For-Profit versus Not-For-Profit Sector: What Difference Does it Make? An Inquiry on Preferences of Voluntary and Involuntary Movers. Industrial and Corporate Change, 23(4), 1087-1120.

Burr, R. and Thomson, P. (2002), 'Expanding the network: What about including "the all" in the psychological contract', Paper presented at the Academy of Management Conference, Denver, USA.

Cesário, F.S., Chambel, M.J. and Guillén, C. (2014), What If Expatriates Decide to Leave? The Mediation Effect of the Psychological Contract Fulfilment, Management Research: The Journal of the American Academy of Management, 12(2), 103-122.

Conway, N. and Briner, R.B. (2002), A Daily Diary Study of Affective Responses To Psychological Contract Breach and Exceeded Promises, Journal of Organizational Behavior, 23, 287-302.

Conway, N. and Briner, R.B. (2005), Understanding psychological contracts at work: A critical evaluation of theory and research. New York: Oxford University Press. 
Conway, N., Guest, D. and Trenberth, L. (2011), Testing the differential effects of changes in psychological contract breach and fulfilment, Journal of Vocational Behavior, 79, 267-276.

Cunningham, I. (2010), Drawing from a bottomless well? Exploring the resilience of value-based psychological contracts in voluntary organizations, The International Journal of Human Resource Management, 21(5), 699-719.

De Hauw, S. and De Vos, A. (2010), Millennials' Career Perspective and Psychological Contract Expectations: Does the Recession Lead to Lowered Expectations? Journal of Business and Psychology, 25(2), 293-302.

Farmer, S.M. and Fedor, D.B. (1999), Volunteer Participation and Withdrawal: A Psychological Contract Perspective on the Role of Expectations and Organizational Support, Nonprofit Management and Leadership, 9(4), 349-367.

Fee, A. (2017, forthcoming), Expatriates in Aidland: Humanitarian aid \& development workers and volunteers. In Y. McNulty and J. Selmer (Eds.), Research Handbook of Expatriates, Cheltenham, Edward Elgar.

Gaston, K. and Alexander, J.A. (2001), Effective organization and management of public sector volunteer workers: Police special constables, International Journal of Public Sector Management, 14(1), 59-74.

Guest, D.E. (2004), The psychology of the employment relationship: An analysis based on the psychological contract, Applied Psychology: An International Review, 53(4), 541-555.

Guest, D.E. and Conway, N. (2002), Communicating Psychological Contract: An Employer Perspective, Human Resource Management Journal, 12, 22-38.

Guzzo, R.A. and Noonan, K.A. (1994), Human Resource Practices as Communications and the Psychological Contract, Human Resource Management, 33(3), 447-462.

Haines III, V.Y., Saba, T. and Choquette, E. (2008), Intrinsic Motivation for an International Assignment, International Journal of Manpower, 29(5), 443-461.

Haski-Leventhal, D. and Bargal, D. (2008), The Volunteer Stages and Transitions Model: Organizational Socialization of Volunteers, Human Relations, 61(1), 67-102. 
Haslberger, A. and Brewster, C. (2009), Capital gains: Expatriate adjustment and the psychological contract in international careers, Human Resource Management, 48(3), 379-397.

Herriot, P. and Pemberton, C. (1997), Facilitating new deals, Human Resource Management Journal, $7(1), 45-56$.

Hudson, S. and Inkson, K. (2006), Volunteer Overseas Development Workers: The Hero's Adventure and Personal Transformation, Career Development International, 11(4), 304-320.

Jassawalla A.R., Asgary N. and Sashittal H.C. (2006), Managing Expatriates: The Role of Mentors, International Journal of Commerce and Management, 16(2), 130-140.

Johnson, J.L. and O’Leary-Kelly, A.M. (2003), The effects of psychological contract breach and organizational cynicism: Not all social exchange violations are created equal, Journal of Organizational Behavior, 24, 627-647.

Kim, M., Trail, G.T., Lim, J. and Kim, Y.K., 2009. The role of psychological contract in intention to continue volunteering. Journal of Sport Management, 23(5), 549-573.

Lester, S.W., Turnley, W.H., Bloodgood, J.M., and Bolino, M.C. (2002), Not seeing eye to eye: Differences in supervisor and subordinate perceptions of and attributions for psychological contract breach, Journal of Organizational Behavior, 23, 39-56.

Liao-Troth, M.A. (2005), Are they here for the long haul? The effects of functional motives and personality factors on the psychological contracts of volunteers, Nonprofit and Voluntary Sector Quarterly, 34(4), 510-530.

Miles, M.B. and Huberman, A.M. (1994), Qualitative data analysis: A sourcebook. Beverly Hills: Sage Publications.

Morrison, E.W. and Robinson, S.L. (1997), When Employees Feel Betrayed: A Model of How Psychological Contract Violation Develops, Academy of Management Review, 22(1), 226-256.

Oberholster, A.J., Clarke, R., Bendixen, M. and Dastoor, B. (2013), Expatriate motivation in religious and humanitarian non-profit-organizations, Journal of Global Mobility: The Home of Expatriate Management Research, 1(1), 7-27.

O’Donohue, W. and Nelson, L. (2009), The Psychological Contracts of Australian Hospital Volunteer Workers, Australian Journal on Volunteering, 14, 1-11. 
O'Donohue, W., Donohue, R. and Grimmer, M.R. (2007), Research into the Psychological Contract: Two Australian Perspectives, Human Resource Development International, 10(3), 301-318.

O'Sullivan, S.L. (2010), International human resource management challenges in Canadian development INGOs, European Management Journal, 28(6), 421-440.

Paik, Y., Segaud, B. and Malinowski, C. (2002), How to Improve Repatriation Management: Are Motivations and Expectations Congruent between the Company and Expatriates? International Journal of Manpower, 23(7), 635-648.

Purvis, L.J.M. and Cropley, M. (2003), Psychological contracting: Processes of contract formation during interviews between nannies and their employers, Journal of Occupational and Organizational Psychology, 76, 213-241.

Quigley, R. L., Claus, L. and Dothan, M. (2015), Medical requests for assistance from globally mobile populations: Contrasting international assignees from different sectors, European Journal of International Management, 9(6), 712-736.

Rafaeli, A. (2006), Sense-making of employment: On whether and why people read employment advertising, Journal of Organizational Behaviour, 27(6), 747-770.

Ralston, R., Downward, P. and Lumsdon, L. (2004), The expectations of volunteers prior to the XVII Commonwealth Games, 2002: A qualitative study, Event Management, 9(1-1), 13-26.

Reilly, R.R., Brown, B., Blood, M. and Maletesta, C. (1981), The Effects of Realistic Job Previews: A Study and Discussion of the Literature, Personnel Psychology, 34, 823-834.

Rigotti, T. (2009), Enough is enough? Threshold models for the relationship between psychological contract breach and job-related attitudes, European Journal of Work and Organizational Psychology, $18(4), 442-463$.

Robinson, S.L. and Rousseau, D.M. (1994), Violating the Psychological Contract: Not the Exception but the Norm, Journal of Organizational Behaviour, 15, 245-259.

Rousseau, D.M. (1989), Psychological and Implied Contracts in Organizations, Employee Responsibilities and Rights Journal, 2(2), 121-139.

Rousseau, D.M. (1995), Psychological Contracts in Organizations: Understanding Written and Unwritten Agreements. Sage, Thousand Oaks, CA. 
Ryan, A.M. and Delany, T. (2010), Attracting job candidates to organizations. In J.L. Farr and N.T. Tippins (Eds.), Handbook of Employee Selection. Routledge, New York, pp. 127-146.

Shore, L.M. and Tetrick, L.E. (1994), The Psychological Contract as an Explanatory Framework in the Employment Relationship. In C. Cooper and D.M. Rousseau (Eds.), Trends in Organizational Behaviour (Vol 1). New York: Wiley, pp. 91-109.

Shore, L.M., Tetrick, L.E., Lynch, P. and Barksdale, K. (2006), Social and Economic Exchange: Construct Development and Validation, Journal of Applied Social Psychology, 36(4), 837-867.

Sims, R.R. (1994), Human Resource Management's Role in Clarifying the New Psychological Contract, Human Resource Management, 33(3), 373-382.

Taylor, M.S. and Tekleab, A.G. (2004), Taking stock of psychological contract research: Assessing progressing, addressing troubleshooting issues, and setting research priorities. In Coyle-Shapiro, J.A.M., Shore, L.M., Taylor, S.M. and Tetrick, L.E. (Eds.), The Employment Relationship: Examining Psychological and Contextual Perspectives. Oxford, Oxford University Press, pp. 253-283.

Taylor, T., Darcy, S., Hoye, R. and Cuskelly, G. (2006), Using psychological contract theory to explore issues in effective volunteer management, European Sport Management Quarterly, 6(2), 123147.

Tekleab, A.G. (2003), The role of realistic job previews and organizational socialization in newcomers' psychological contract development. PhD Thesis, University of Maryland.

Tekleab, A.G., and M.S. Taylor (2003), Aren't there two parties in an employment relationship? Antecedents and consequences of organization-employee agreement on contract obligations and violations, Journal of Organizational Behavior, 24, 585-608.

Thomas, H.D.C. and Anderson, N. (1998), Changes in Newcomers' Psychological Contracts during Organizational Socialization: A Study of Recruits Entering the British Army, Journal of Organizational Behavior, 19, 745-767.

Thompson, J.A. and Bunderson, J.S. (2003), Violations of Principle: Ideological Currency in the Psychological Contract, Academy of Management Review, 28(4), 571-587.

Tomprou, M. and Nikolaou, I. (2011), A Model of Psychological Contract Creation Upon Organizational Entry, Career Development International, 16, 342-363. 
Tsui, A. S., Pearce, J.L, Porter, L. W. and Tripoli, A. M. (1997), Alternative Approaches to the Employee-Organizational Relationship: Does Investing in Employees Pay Off, Academy of Management Journal, 40(5), 1089-1121.

Vantilborgh, T., Bidee, J., Pepermans, R., Willems, J., Huybrechts, J. and Jegers, M. (2012), Volunteers' Psychological Contracts: Extending Traditional Views, Nonprofit and Voluntary Sector Quarterly, 41(6), 1072-1091.

Zhao, H.A.O., Wayne, S.J., Glibkowski, B.C. and Bravo, J. (2007), The impact of psychological contract breach on work-related outcomes: a meta-analysis. Personnel Psychology, 60(3), 647-680. 
Table 1: Domestic Volunteers' Perceptions of Organizational Obligations

\begin{tabular}{|l|l|}
\hline Term & Definition \\
\hline Autonomy & $\begin{array}{l}\text { Allow volunteers to perform volunteer activities with minimal organizational } \\
\text { interference }\end{array}$ \\
\hline Benefits & Provide tangible inducements and free or discounted activities to volunteers \\
\hline Communication & Consult and effectively communicate with volunteers on matters affecting them. \\
\hline Contributing to the mission & $\begin{array}{l}\text { Stimulate and facilitate volunteers to contribute to the organization's espoused } \\
\text { cause/mission/values }\end{array}$ \\
\hline $\begin{array}{l}\text { Credible commitment to the } \\
\text { mission }\end{array}$ & $\begin{array}{l}\text { Demonstrate a credible commitment to the organizations' espoused } \\
\text { cause/mission/values }\end{array}$ \\
\hline Fairness & Fair and consistent application of rules and procedures \\
\hline $\begin{array}{l}\text { Friendship } \\
\text { Humanity }\end{array}$ & $\begin{array}{l}\text { Provide opportunities for social interaction, stimulate a sense of belonging and } \\
\text { a good atmosphere }\end{array}$ \\
\hline Input & Act in a personally and socially supportive way toward volunteers \\
\hline Recognition & Give volunteers input in the organizations' management and governance \\
\hline Support & $\begin{array}{l}\text { Psychological rewards (by organization, colleagues or customers) in return for } \\
\text { contributions/effort }\end{array}$ \\
\hline Training & Adequate organizational support enabling basic execution of volunteer tasks \\
\hline & Adequate induction and training \\
\hline
\end{tabular}

Source: Adapted from Vantilborgh et al. (2012, p.1081) 
Table 2: Profiles of International Volunteers and their Assignments

\begin{tabular}{|c|c|c|c|c|c|c|c|}
\hline $\begin{array}{c}\text { Coded } \\
\text { name }\end{array}$ & $\begin{array}{l}\text { No. of inter } \\
\text { views }\end{array}$ & $\begin{array}{l}\text { Gen } \\
\text { der }\end{array}$ & Age & $\begin{array}{l}1^{\text {st }} \text { over- } \\
\text { seas assign } \\
\text { ment? }\end{array}$ & $\begin{array}{l}\text { Assign } \\
\text { ment } \\
\text { length }\end{array}$ & $\begin{array}{l}\text { Country of } \\
\text { assignment }\end{array}$ & Type of work \\
\hline \multicolumn{8}{|c|}{ Long term volunteers } \\
\hline Ann & 1 & $\mathrm{~F}$ & 40 & Yes & 1.5 years & Tanzania & Teaching \\
\hline Renee & 2 & $\mathrm{~F}$ & 57 & Yes & 3 years & Vietnam & Teaching \\
\hline Karen & 1 & $\mathrm{~F}$ & 45 & Yes & 1 years & Egypt & $\begin{array}{l}\text { Administration duties for a program helping } \\
\text { displaced Africans in Cairo. }\end{array}$ \\
\hline Andrew & 1 & $M$ & 42 & No & 2 years & Zambia & $\begin{array}{l}\text { Outreach work with head missionary; young } \\
\text { adult mentor at local church; HIV/AIDS educator } \\
\text { with high schools }\end{array}$ \\
\hline Graham & 1 & $M$ & 62 & No & 2.5 years & Afghanistan & $\begin{array}{l}\text { Train Afghan eye doctors in surgical and } \\
\text { diagnostic manoeuvres }\end{array}$ \\
\hline Kara & 2 & $\mathrm{~F}$ & 32 & No & 2 years & Vietnam & Nursing \\
\hline Megan & 1 & $\mathrm{~F}$ & 54 & No & 2 years & Vietnam & Nursing \\
\hline Peter & 2 & $M$ & 53 & No & 1.5 years & Vietnam & Teaching \\
\hline Tina & 1 & $\mathrm{~F}$ & 56 & No & 2.5 years & Cambodia & Teaching \\
\hline Trish & 1 & $\mathrm{~F}$ & 52 & No & 1 year & Cambodia & Teaching \\
\hline Lena & 1 & $\mathrm{~F}$ & 29 & No & 1 year & Vietnam & Teaching \\
\hline \multicolumn{8}{|c|}{ Short term volunteers } \\
\hline Willow & 1 & $\mathrm{~F}$ & 33 & Yes & 1 month & Argentina & Working at an orphanage \\
\hline Stacey & 1 & $\mathrm{~F}$ & 36 & Yes & 2 weeks & Vietnam & $\begin{array}{l}\text { Teaching at local school, teaching English to } \\
\text { students and local teachers }\end{array}$ \\
\hline Claire & 1 & $\mathrm{~F}$ & 38 & Yes & 2 weeks & Uganda & Building classroom and general assistance \\
\hline Sarah & 1 & $\mathrm{~F}$ & 52 & Yes & 4 weeks & India & Discussing work of IAD with indigenous groups \\
\hline Fiona & 1 & $\mathrm{~F}$ & 33 & No & 2 weeks & Cambodia & \\
\hline Brooke & 1 & $\mathrm{~F}$ & 34 & No & 2 weeks & Uganda & Assisting in classrooms; helping build a classroom \\
\hline Paul & 1 & M & 32 & No & 2 weeks & Fiji & Running a training and accommodation centre \\
\hline Rebecca & 1 & $\mathrm{~F}$ & 37 & No & 10 days & Uganda & Working at an orphanage and building a classroom \\
\hline Rachel & 1 & $\mathrm{~F}$ & 22 & No & 2 week`s & Honduras & $\begin{array}{l}\text { Education (leading seminars on health/water for } \\
\text { rural Honduran children); manual labour } \\
\text { (digging trenches, laying water pipes) }\end{array}$ \\
\hline Wendy & 1 & $\mathrm{~F}$ & 36 & No & 11 weeks & Laos & $\begin{array}{l}\text { Teaching English as a second language, } \\
\text { making materials and resources }\end{array}$ \\
\hline Wesley & 2 & M & 33 & No & $\begin{array}{l}2 \text { weeks } \\
\text { (repeatedl) }\end{array}$ & Vanuatu & Training local church ministers \\
\hline Anthony & 2 & M & 56 & No & $\begin{array}{l}2 \text { weeks } \\
\text { (repeatedll) }\end{array}$ & Philippines & $\begin{array}{l}\text { Construction work, teaching, co-ordinating, } \\
\text { emergency aid }\end{array}$ \\
\hline Jeff & 1 & M & $>65$ & No & $\begin{array}{l}2 \text { weeks } \\
\text { (repeatedl) }\end{array}$ & Philippines & $\begin{array}{l}\text { Construction work, teaching, co-ordinating, } \\
\text { emergency aid }\end{array}$ \\
\hline Michael & 1 & M & $>60$ & No & $\begin{array}{l}2 \text { weeks } \\
\text { (repeatedl) }\end{array}$ & $\begin{array}{l}\text { Papua New } \\
\text { Guinea }\end{array}$ & Construction work, teaching, co-ordinating \\
\hline Joyce & 1 & $\mathrm{~F}$ & $>50$ & No & $\begin{array}{l}2 \text { weeks } \\
\text { (repeatedl) }\end{array}$ & $\begin{array}{l}\text { Papua New } \\
\text { Guinea }\end{array}$ & $\begin{array}{l}\text { Co-ordinating women' hygiene, birth support } \\
\text { projects, application writing support }\end{array}$ \\
\hline Jude & 1 & M & 38 & No & $\begin{array}{l}2 \text { weeks } \\
\text { (repeatedl) }\end{array}$ & Philippines & Construction work, emergency aid \\
\hline
\end{tabular}


Table 3: Organizational Obligations of Domestic and International Volunteers

\begin{tabular}{|c|c|c|c|}
\hline PC Item & Definition & Quote (Volunteers) & Quote (International Volunteers) \\
\hline Autonomy (R) & $\begin{array}{l}\text { Provide the ability to } \\
\text { autonomously } \\
\text { perform volunteer } \\
\text { activities, with } \\
\text { minimal } \\
\text { organizational } \\
\text { interference }\end{array}$ & $\begin{array}{l}\text { "When we started working with our } \\
\text { team, we told [the organization] that } \\
\text { we would do the tasks but we would } \\
\text { do it our way. And they allowed us } \\
\text { to do it how we wanted it." }\end{array}$ & \\
\hline Benefits (T) & $\begin{array}{l}\text { Provide tangible } \\
\text { inducements and } \\
\text { free or discounted } \\
\text { activities to } \\
\text { volunteers }\end{array}$ & $\begin{array}{l}\text { "We were at a festival, giving away a } \\
\text { card game box as advertisement for } \\
\text { the organization. The ground was } \\
\text { littered with thrown away cards, but } \\
\text { if we wanted a box for ourselves, we } \\
\text { had to pay for it." }\end{array}$ & \\
\hline $\begin{array}{l}\text { Communication } \\
\text { (T) }\end{array}$ & $\begin{array}{l}\text { Consult and } \\
\text { effectively } \\
\text { communicate with } \\
\text { volunteers on } \\
\text { matters that affect } \\
\text { them }\end{array}$ & $\begin{array}{l}\text { "They ought to inform volunteers on } \\
\text { their tasks on [the annual] members } \\
\text { day. But no one knew what to do ... } \\
\text { They need to communicate more... } \\
\text { It has already cost them a lot of } \\
\text { volunteers." }\end{array}$ & \\
\hline $\begin{array}{l}\text { Communication } \\
\text { with family, } \\
\text { home base of } \\
\text { the IAD (R) }\end{array}$ & $\begin{array}{l}\text { Assist volunteers to } \\
\text { communicate with } \\
\text { their families and } \\
\text { the organization's } \\
\text { home base }\end{array}$ & & $\begin{array}{l}\text { Andrew: "The [IAD mission's wing] } \\
\text { member would visit once a month } \\
\text { for each of the three months. [We] } \\
\text { caught up for coffee, chatted." } \\
\text { Other volunteers kept in touch with } \\
\text { their families and IAD head office, } \\
\text { when necessary, using their own } \\
\text { means. }\end{array}$ \\
\hline $\begin{array}{l}\text { Contribute to } \\
\text { organization's } \\
\text { mission (V) }\end{array}$ & $\begin{array}{l}\text { Facilitate/stimulate } \\
\text { volunteers to } \\
\text { contribute to the } \\
\text { organization's } \\
\text { espoused cause/ } \\
\text { mission/values }\end{array}$ & $\begin{array}{l}\text { "We notice a lack of effort with the } \\
\text { younger generation of volunteers. It } \\
\text { seems like every extra effort is too } \\
\text { much to ask. We often discuss this } \\
\text { with them... but it seems to have no } \\
\text { effect." }\end{array}$ & $\begin{array}{l}\text { Sarah: "They could certainly use the } \\
\text { skills of volunteers much more after } \\
\text { we come back. [...] They are not } \\
\text { well set up to deal with the training } \\
\text { and experience that we have and I } \\
\text { think that is a loss for them." }\end{array}$ \\
\hline $\begin{array}{l}\text { Credible } \\
\text { commitment to } \\
\text { organization's } \\
\text { mission (V) }\end{array}$ & $\begin{array}{l}\text { Demonstrate a } \\
\text { credible } \\
\text { commitment to the } \\
\text { organization's } \\
\text { espoused cause/ } \\
\text { mission/values }\end{array}$ & $\begin{array}{l}\text { "The central staff of the organization } \\
\text { often says that everything is going } \\
\text { great with the students we help, } \\
\text { while we notice that they are having } \\
\text { problems. They need to be realistic." }\end{array}$ & \\
\hline Fairness (V) & $\begin{array}{l}\text { Fair and consistent } \\
\text { application of rules } \\
\text { and procedures }\end{array}$ & $\begin{array}{l}\text { "We were unaware that you can ask } \\
\text { the organization for a tax certificate. } \\
\text { Until another volunteer told us that } \\
\text { they had been getting that certificate } \\
\text { for years, but that you had to } \\
\text { explicitly ask the organization for it. I } \\
\text { felt that was not right and that the } \\
\text { organization should give those } \\
\text { certificates automatically to } \\
\text { everyone." }\end{array}$ & \\
\hline Friendship (R) & $\begin{array}{l}\text { Opportunity for social } \\
\text { interaction, } \\
\text { stimulate a sense } \\
\text { of belonging and a } \\
\text { good atmosphere }\end{array}$ & $\begin{array}{l}\text { "I expected to meet many new and } \\
\text { interesting people, but I never } \\
\text { expected these friendships to be so } \\
\text { profound. The workshops and } \\
\text { weekends that are organized really } \\
\text { make you bond ... and this is really } \\
\text { stimulating." }\end{array}$ & $\begin{array}{l}\text { Jeff: "When you go over there you are } \\
\text { like-minded people with a human- } \\
\text { itarian interest so you do become a } \\
\text { family. [...] A lot of us have seen } \\
\text { awful things - people who are dying, } \\
\text { decomposing corpses in natural } \\
\text { disasters - but I think it's that group } \\
\text { bonding, and that family situation } \\
\text { that [means] you just move on." }\end{array}$ \\
\hline
\end{tabular}




\begin{tabular}{|c|c|c|c|}
\hline Humanity (V) & $\begin{array}{l}\text { Act in a personally } \\
\text { and socially } \\
\text { supportive way } \\
\text { toward volunteers }\end{array}$ & $\begin{array}{l}\text { "They were thoughtless [about my } \\
\text { transfer to a new function]... . }\end{array}$ & \\
\hline Input (R) & $\begin{array}{l}\text { Give volunteers input } \\
\text { in the } \\
\text { organizations' } \\
\text { management and } \\
\text { governance }\end{array}$ & $\begin{array}{l}\text { I had very little chance to say } \\
\text { something at the first general } \\
\text { assembly meeting that I attended. }\end{array}$ & $\begin{array}{l}\text { Sarah: "I got an invitation in the mail } \\
\text { to vote for members of the executive } \\
\text { committee [of the IAD] at its next } \\
\text { annual general meeting. But I didn't } \\
\text { know the candidates well enough to } \\
\text { make an informed vote. The } \\
\text { organization could have fixed that." }\end{array}$ \\
\hline Recognition (R) & $\begin{array}{l}\text { Psychological } \\
\text { rewards (by } \\
\text { organization, } \\
\text { colleagues or } \\
\text { customers) in } \\
\text { return for con- } \\
\text { tributions/effort }\end{array}$ & $\begin{array}{l}\text { "Since last year they organize a day } \\
\text { for the volunteers... It signals they } \\
\text { don't just want to give us tasks, but } \\
\text { that they also want to give } \\
\text { something back to us as an } \\
\text { organization." }\end{array}$ & $\begin{array}{l}\text { Joyce: "[The IAD] gave everyone a } \\
\text { certificate in a ceremony.... It really } \\
\text { brings a tear to your eyes and it } \\
\text { makes you feel, 'Geez, they really } \\
\text { appreciate what we have done'." }\end{array}$ \\
\hline Support (T) & $\begin{array}{l}\text { Adequate } \\
\text { organizational } \\
\text { support enabling } \\
\text { basic execution of } \\
\text { volunteer tasks }\end{array}$ & $\begin{array}{l}\text { "They make sure that everything is } \\
\text { there: all the paperwork is done, all } \\
\text { the material for our events is in } \\
\text { place. When we organize a party, } \\
\text { they bring the food and drinks, they } \\
\text { rent the venue, and make sure all } \\
\text { the rented equipment is in place." }\end{array}$ & $\begin{array}{l}\text { EXPERIENCED (Wesley): "[We only } \\
\text { expect] them to provide the real } \\
\text { basics, like logistics and safety. } \\
\text { Things like emergency exits in } \\
\text { disaster zones, and help with } \\
\text { communication when we're in } \\
\text { remote locations with no mobile } \\
\text { coverage. [...] The main expectation } \\
\text { we had of the organization was to } \\
\text { arrange the booking and logistics for } \\
\text { being there. But even if those failed } \\
\text { we strongly believed that God would } \\
\text { still provide us with opportunities to } \\
\text { serve and fulfil our reason for being } \\
\text { there." } \\
\text { INEXPERIENCED (Jeff): "We [the } \\
\text { volunteers] just get in and do it. If } \\
\text { we are taking a new person up, we } \\
\text { just talk them through it [what's got } \\
\text { to be done] probably in the morning } \\
\text { over breakfast." }\end{array}$ \\
\hline $\begin{array}{l}\text { Spiritual } \\
\text { support (V) }\end{array}$ & $\begin{array}{l}\text { Prayer for the } \\
\text { volunteer }\end{array}$ & & $\begin{array}{l}\text { FAITH-BASED (Kara): "Some } \\
\text { [patients] you can save, some you } \\
\text { can't. Some cases like deformities } \\
\text { could be fixed in Australia, but in } \\
\text { Vietnam, the patients have to suffer } \\
\text { for years in isolation and have no } \\
\text { hope because they are just so poor. } \\
\text { Praying within our group gives me } \\
\text { inner strength, reinforces my belief } \\
\text { in what I am doing, and keeps me } \\
\text { going." }\end{array}$ \\
\hline Training (T) & $\begin{array}{l}\text { Adequate induction } \\
\text { and training }\end{array}$ & $\begin{array}{l}\text { "There was absolutely no induction for } \\
\text { new volunteers. I brought a friend of } \\
\text { mine to come take a look, but it } \\
\text { didn't go well as no one paid } \\
\text { attention to her. I mentioned this to } \\
\text { the management and they started } \\
\text { paying attention to it." }\end{array}$ & $\begin{array}{l}\text { INEXPERIENCED (Michael): "There } \\
\text { is a legacy coming through by word } \\
\text { of mouth. I don't think there is any } \\
\text { formal training. I think we have peer } \\
\text { knowledge." } \\
\text { EXPERIENCED (Tina): "[The IAD] } \\
\text { should try to get to know the people } \\
\text { they are sending overseas, make } \\
\text { sure they have good bible and } \\
\text { cross-cultural training." }\end{array}$ \\
\hline
\end{tabular}

$\mathrm{T}=$ Transactional, $\mathrm{R}=$ Relational, $\mathrm{V}=$ Values-based

Source: Authors' analysis of IV interviews and Vantilborgh (2012). 